\title{
Assessment of boron-containing compounds and oleoylethanolamide supplementation on the recovery trend in patients with COVID-19: A structured summary of a study protocol for a randomized controlled trial
}

Helda Tutunchi ${ }^{1}$, Majid Mobasseri ${ }^{2}$, Samira Pourmoradian ${ }^{3}$, Hamid Soleimanzadeh ${ }^{4}$, Behnam Kafil ${ }^{3}$, Neda Akbari ${ }^{3}$, Alireza Monshikarimi $^{3}$ and Alireza Ostadrahimi ${ }^{{ }^{*}}$

\begin{abstract}
Objectives: In this study, we investigate the effect of boron-containing compounds and oleoylethanolamide supplementation on the recovery trend in patients with COVID-19.

Trial design: The current study is a single-center, randomized, double-blind, placebo-controlled clinical trial with parallel groups.

Participants: The inclusion criteria include male and female patients $\geq 18$ years of age, with a confirmed diagnosis of SARS-CoV-2 infection via polymerase chain reaction (PCR) and/or antibody test and with written informed consent to participate in this trial. The exclusion criteria include regular use of any other supplement, severe and critical COVID-19 pneumonia, pregnancy and breastfeeding. This study is being conducted at Imam Reza Hospital, Tabriz University of Medical Sciences, Tabriz, Iran.

Intervention and comparator: Patients are randomly assigned to four groups. The first group (A) will take one capsule containing $5 \mathrm{mg}$ of boron compounds twice a day for two weeks. The second group (B) will take one capsule containing $200 \mathrm{mg}$ oleoylethanolamide twice a day for two weeks. The third group (C) will take one capsule containing $5 \mathrm{mg}$ boron compounds with $200 \mathrm{mg}$ oleoylethanolamide twice a day for two weeks, and the fourth group (D) does not receive any additional treatment other than routine treatments. Boron-containing compounds and oleoylethanolamide capsules will be synthesized at Nutrition Research Center of Tabriz University of Medical Sciences.

\footnotetext{
* Correspondence: ostadrahimi@tbzmed.ac.ir

'Department of Clinical Nutrition, Nutrition Research Center, School of Nutrition \& Food Sciences, Tabriz University of Medical Sciences, Tabriz 5166614711 , Iran

Full list of author information is available at the end of the article
}

(c) The Author(s). 2020 Open Access This article is licensed under a Creative Commons Attribution 4.0 International License, which permits use, sharing, adaptation, distribution and reproduction in any medium or format, as long as you give appropriate credit to the original author(s) and the source, provide a link to the Creative Commons licence, and indicate if changes were made. The images or other third party material in this article are included in the article's Creative Commons licence, unless indicated otherwise in a credit line to the material. If material is not included in the article's Creative Commons licence and your intended use is not permitted by statutory regulation or exceeds the permitted use, you will need to obtain permission directly from the copyright holder. To view a copy of this licence, visit http://creativecommons.org/licenses/by/4.0/. The Creative Commons Public Domain Dedication waiver (http://creativecommons.org/publicdomain/zero/1.0/) applies to the data made available in this article, unless otherwise stated in a credit line to the data. 
(Continued from previous page)

Main outcomes: The primary end point of this study is to investigate the recovery rate of clinical symptoms, including fever, dry cough, and fatigue, as well as preclinical features, including complete blood count (CBC), the erythrocyte sedimentation rate (ESR), C-reactive protein (CRP) profiles within two weeks of randomization.

Randomisation: Patients are randomized into four equal groups in a parallel design (allocation ratio 1:1). A randomized block procedure is used to divide subjects into one of four treatment blocks $(A, B, C$, and D) by a computer-generated allocation schedule.

Blinding (masking): The participants and investigators (enrolling, assessing, and analyzing) are blinded to the intervention assignments until the end of the study and data analysis.

Numbers to be randomised (sample size): The calculated total sample size is 40 patients, with 10 patients in each group.

Trial Status: The protocol is Version 1.0, May 17, 2020. Recruitment began May 19, 2020, and is anticipated to be completed by October 19, 2020.

Trial registration: This clinical trial has been registered by the title of "Assessment of boron-containing compounds and oleoylethanolamide supplementation on the recovery trend in Patients with COVID-19: A double-blind randomized placebo-controlled clinical trial" in the Iranian Registry of Clinical Trials (IRCT). The registration number is "IRCT20090609002017N35", https://www.irct.ir/trial/48058. The registration date is 17 May 2020.

Full protocol: The full protocol is attached as an additional file, accessible from the Trials website (Additional file 1). In the interest in expediting dissemination of this material, the familiar formatting has been eliminated; this Letter serves as a summary of the key elements of the full protocol.

Keywords: COVID-19, Randomised controlled trial, Protocol, Oleoylethanolamide, Boron-containing compounds, Complete blood count, Erythrocyte sedimentation rate, C-reactive protein

\section{Supplementary information}

Supplementary information accompanies this paper at https://doi.org/10. 1186/s13063-020-04820-2.

\section{Additional file 1}

\section{Acknowledgements}

The authors like to thank all the nurses and medical staff who dedicated their time and effort to managing patients during COVID-19 pandemic.

\section{Authors' contributions \\ Study design and protocol development: $\mathrm{AO}$ and MM. Manuscript preparation: HT. Laboratory work: HS and BK. All aspects of the study conduction: HT, SP, NK and AM. The authors read and approved the final manuscript before submission.}

\section{Funding}

This trial has been supported by Tabriz University of Medical Sciences, Tabriz Iran. The funders have no role in the design of the trial, the intervention procedures, collection, evaluation, and analysis of data.

\section{Availability of data and materials}

The corresponding author has access to the final dataset of the trial, and the data will be available on reasonable request (Contact: Ostadrahimi@tbzmed. ac.ir).

\section{Ethics approval and consent to participate}

The present trial was approved by the Ethics Committee of Tabriz University of Medical Sciences (Ethics committee reference number:

IR.TBZMED.REC.1399.099) on May 06, 2020. The investigators declare the trial has received ethical approval from the appropriate ethical committee, as described above. Informed written consent will be obtained from all participants.

\section{Consent for publication}

Not applicable.

\section{Competing interests}

The authors declare that they have no competing interests.

\section{Author details}

${ }^{1}$ Department of Clinical Nutrition, Nutrition Research Center, School of Nutrition \& Food Sciences, Tabriz University of Medical Sciences, Tabriz 5166614711, Iran. ${ }^{2}$ Endocrine Research Center, Tabriz University of Medical Sciences, Tabriz, Iran. ${ }^{3}$ Nutrition Research Center, Tabriz University of Medical Sciences, Tabriz, Iran. ${ }^{4}$ Department of Applied Chemistry, Faculty of Chemistry, University of Tabriz, Tabriz, Iran.

Received: 29 September 2020 Accepted: 16 October 2020 Published online: 27 October 2020

\section{Publisher's Note}

Springer Nature remains neutral with regard to jurisdictional claims in published maps and institutional affiliations.
Ready to submit your research? Choose BMC and benefit from:
- fast, convenient online submission
- thorough peer review by experienced researchers in your field
- rapid publication on acceptance
- support for research data, including large and complex data types
- gold Open Access which fosters wider collaboration and increased citations
- maximum visibility for your research: over $100 \mathrm{M}$ website views per year
At BMC, research is always in progress.
Learn more biomedcentral.com/submission 